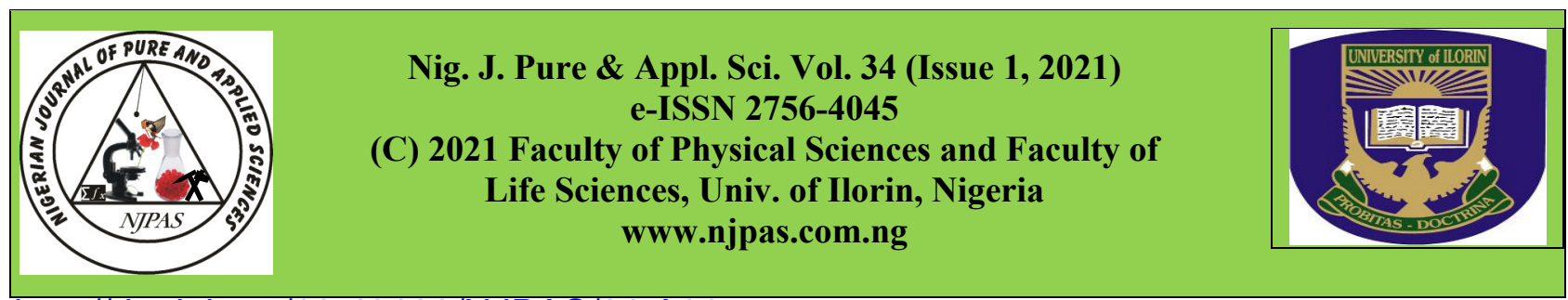

http://dx.doi.org/10.48198/NJPAS/21.A06

\title{
Appraisal of Public Opinions Towards Potential COVID-19 Vaccination in FCT-Abuja Nigeria
}

\author{
${ }^{* 1}$ Obafemi, F.A., ${ }^{1}$ Olabode, H.O.K. and ${ }^{2}$ Edeh, M.O.
}

Page | 3962

${ }^{1}$ Faculty of Veterinary Medicine, University of Abuja, Nigeria

${ }^{2}$ Dept. of Mathematics and Computer Science, Coal City University, Nigeria

\begin{abstract}
The emergence of the novel Coronavirus Disease in 2019 (COVID-19) in Wuhan, China, and the subsequent global threat, resulting in the current pandemic in over 215 countries, characterized by alarming morbidity, mortality, and social effects in affected humans, as well as an economic downturn due to national and international border closures used as a containment strategy, necessitated this study to assess the opinions of the public on the potential vaccination against COVID-19. This research primarily aims to provide policy makers with useful information on public perceptions of the disease, as well as public knowledge and preparedness for its prevention and eventual eradication. Two hundred (200) organized open-ended questionnaires were distributed at random across the six (6) Area Councils in Abuja, Nigeria. The responses were subjected to the Pearson Chi-Square Test at a CI of $95 \%$ and a level of significance of 5\%. Of the 1200 respondents sampled, $976(81.3 \%)$ were willing to be immunized if vaccines were available. However, $5(0.4 \%)$ respondents expressed indifference, while 219 (18.3\%) respondents did not support the use of COVID-19 vaccine for a variety of reasons, including a lack of confidence in the vaccine, belief in God for COVID-19 virus safety, and fear and dislike of injectable drugs. Thus, showing a vaccine response that was significantly affected by religion, marital status and education $(\mathrm{P}<0.05)$. According to the results of the current study, respondents believe the novel Coronavirus has the potential to cause varying degrees of damage, eventually leading to death. However, their response revealed that vaccine acceptance could be hampered by distrust and other apprehensions. As a result, vaccinations must be implemented strategically and with enough publicity for the intent of enlightenment, empowering citizens to adopt the established intervention mechanism.
\end{abstract}

Keywords: COVID-19, Vaccination

\section{Introduction}

Coronaviruses are positive-sense, single-stranded RNA (ssRNA) viruses with genomes of $27-32 \mathrm{~kb}$ and spherical particles measuring $100-160 \mathrm{~nm}$ in diameter that belong to the Coronaviridae subfamily of the Coronaviridae family and order Nidovirales (ICTV) (Cui et al., 2019).
Alphacoronavirus, Beta-coronavirus, Gammacoronavirus, and Delta-coronavirus are the four genera that make up this subfamily (Graham et al., 2013).

Alpha coronaviruses and Beta Coronaviruses only infect mammals, while Gamma Coronaviruses and

Corresponding Author: Dr. Obafemi, FA.

Faculty of Veterinary Medicine, University of Abuja, Nigeria

Email: faithoba@ymail.com 
Delta Coronaviruses mostly infect birds, but some can also infect mammals (Woo et al., 2012). HKU1, NL63, OC43, 229E, SARS-CoV, MERS$\mathrm{CoV}$ are the six (6) identified coronaviruses that have infected humans (Corman et al., 2018), with Page | 3963 SARS-CoV-2 being the seventh (Zhou et al., 2020). SARS-CoV-2, SARS-CoV-1, and MERS coronaviruses are all members of the Beta coronavirus family and have been linked to serious illness, while HCoV-OC43, NL63, 229E, and $\mathrm{HCoV}-\mathrm{HKU} 1$ have been linked to asymptomatic to moderate upper respiratory tract illness ( $\mathrm{Su}$ et al., 2016). This latest SARS-COV-2 outbreak in December 2019 began in a local seafood market in Wuhan, Hubei province in Central China (Zhou et al., 2020), with most initial infections not causing serious disease (CCDC, 2020), but it was believed to infect more people (Zou, et al., 2020) with the potential for large-scale population spread in various countries (Zou et al., 2020; Callaway, 2020).

The SARS-COV-2 strain of Coronavirus is novel, but it has already had a negative impact on humanity (Onyema et al., 2020). As of April 2020, the global COVID-19 case count had reached one million cases, with over 220,000 deaths (Onyema et al., 2020). Most SARS-related Coronaviruses were discovered in their natural bat reservoirs ( $\mathrm{Li}$ et al., 2005), and this virus was transmitted directly to humans from market mammals (Guan et al., 2003), and then human to human (Zhou et al., 2020), as well as transmission through contaminated surfaces (WHO, 2020a).

Fever, dry cough, breathing problems (dyspnoea), headache, pneumonia, gradual respiratory failure, and even death are common clinical symptoms of affected patients (Zhou et al., 2020; Onyema et al., 2020b). The risk of symptomatic infection increases with age, especially among adults aged 30-60 years, with a high mortality rate in those under 30 and over 60 years (Wu et al., 2020; Mohit et al., 2020). The earlier virus spread was linked to predisposing factors like overcrowding and increased human interaction in super-spreading events and settings like the Diamond Princess Cruise ship, Chinese jails, and Daegu church in South Korea (Liu, 2020).

In 1918, a virulent type A virus triggered an influenza pandemic in Nigeria, which resulted in a short-term demographic catastrophe marked by widespread death and low national productivity (Ohadike, 1991). Similarly, the first index case in this current plaque was detected on February 27, 2020 , and the outbreak has continued to spread through 19 states, including the Federal Capital Territory, with a total of 493 confirmed cases, 317 active cases, 159 discharges, and 17 deaths in the country 50 days after virus identification (NCDC, 2020a).

The NCDC recommends social distancing, hand washing with soap and sanitizers, and avoiding large and overcrowded gatherings, as well as human and vehicular travel limits, to prevent the virus from spreading (NCDC, 2020b).

Except for symptomatic care of infected patients, there is no known treatment for SARS Coronavirus (SARS-COV) and SARS-COV-2 (Hilgenfeld and Peiris, 2013). However, timely evidence from clinical trials of Remdesivir, lopinavir/ritonavir, and other possible chemotherapies will be apt and formidable in combating COVID-19 (Wu et al., 2020). Reports of drug repurposing studies and in vitro cell culture drug effect on COVID-19 cells indicated that ivermectin (Caly et al., 2020), chloroquine, favipiravir, remdesivir, and other existing broad-spectrum antiviral agents and antibiotics (Teicoplanin, Oritavancin, Dalbavancin, and Monensin) showed promising results at various stages of trials; nevertheless, the (Andersen et al., 2020). Cyclohexylmethyl (11r) has shown possible antiviral activity against SARCOV, MERS-COV, and the recent Coronavirus (Zhang et al., 2020). Six other compounds, like Ebselen, have potentially inhibited the crystal structure of COVID-19 virus $\mathrm{M}^{\text {pro }}$ (also known as 3CL Protease) (Haito et al., 2020).

According to Yang et al. (2020), despite the fact that there's yet to be an approved vaccine, 
the vaccination of susceptible populations is essentially an acceptable and best practice for controlling SARS-COV and MERS-COV infections, including a vaccine against the recent Coronavirus SARS-COV-2 infections, because Page | 3964 vaccine production is a costly, time-consuming, and labor-intensive process that involves many vaccine candidates and several years to produce a licensed vaccine (Gouglas et al., 2018).

In the midst of the current pandemic, scientists around the world have stepped up efforts to conduct numerous studies for future vaccine production on a variety of scales, with encouraging results. According to the World Health Organization, there are over 70 COVID-19 vaccine candidates worldwide, three of which are in clinical trials at the time of this study (WHO, 2020c); Nigeria has indicated interest in solidarity in this clinical trial and control efforts (WHO, 2020d). The aim of this study is to evaluate public readiness for COVID-19 vaccination in the event of potential and early vaccine development.

\section{Materials and Methods \\ Study Area}

The Federal Capital Territory (FCT) is located between latitudes $8.25^{\circ} \mathrm{N}$ and $9.20^{\circ} \mathrm{N}$ of the equator and longitudes $6.45^{\circ} \mathrm{E}$ and $7.39^{\circ} \mathrm{E}$ east of the Greenwich Meridian and shares borders with the states of Kogi, Kaduna, Niger, and Nasarawa. Abuja, with a landmass of approximately 7,315 $\mathrm{km}^{2}$, is geographically located in the center of the country. The territory is divided into six area councils: Abaji, Abuja Municipal, Gwagwalada, Kuje, Bwari, and Kwali (Olabode et al., 2011) and has a total estimated population of 2,238,800 people (FCT Development Authority, 2015). The unique location, activity of the international airport and city function as the national administrative center premised this study.

\section{Study Design}

Over a four-week span, questionnaires were randomly distributed to individuals as they went out jogging, strolling, or shopping on days approved by the government during the lockdown, while adhering to NCDC safety measures such as hand sanitizers, nose masks, hand gloves, and maintaining a physical distance of at least two meters. Throughout the report, the data collectors had digital thermometers in their possession at all times. In total, 200 people were interviewed in each of the six area councils, for a total of 1,200 respondents in this survey. The data collectors took care of and registered all answers to the questionnaire description.

\section{Questionnaire}

Questions outlined in the questionnaire include: name, gender, age, religion, marital status, number of children, state of origin, state of residence, highest educational qualification, job, if vaccine would be accepted and taken when produced and reasons why if not.

\section{Data Analysis}

Frequency and percentage were used to represent the data. The association between variables was determined using Pearson's Chi square test, with a P-value of 0.05 and a $95 \%$ confidence interval. All analysis was performed using SPSS version 21 (2015).

\section{Results}

In the current study, the male population in all council areas was higher than the female population. In all six area councils studied, males made up $81.0 \%(n=973)$ of the total population studied, compared to their female counterparts $(18.5 \% ; n=222)$.

The distribution of vaccination response for COVID-19 vaccines in Abuja is shown in Table 1. There was a statistically significant relationship between gender and vaccination response rate $(\mathrm{p}<0.05)$ in Abuja Municipal Area Council; of the 200 participants, $50.0 \%(\mathrm{n}=100)$ of males and $31.0 \% \quad(\mathrm{n}=62)$ of females agreed to obtain 
vaccinations. This acceptance rate was higher than in Gwagwalada Area Council, where 40.5\% $(n=81)$ of males and $19.5 \%(n=39)$ of females agreed to receive COVID-19 vaccines when they became available.
Kwali Area Council had the highest acceptance rate among males and females, with $60.0 \%(n=120)$ males and $36.5 \%(n=73)$ females agreeing to receive COVID-19 vaccines if offered.

Table 1: Distribution of Vaccination response for COVID-19 vaccine in Abuja-FCT, Nigeria

\begin{tabular}{|c|c|c|c|c|c|c|c|c|c|}
\hline \multirow{2}{*}{\begin{tabular}{|l|} 
Location \\
$\mathrm{AMC}$ \\
\end{tabular}} & \multirow[t]{2}{*}{ Gender } & \multicolumn{4}{|c|}{ Vaccination Response Freq. (\%) } & \multirow{2}{*}{$\begin{array}{l}\text { Gender } \\
\text { Frequency }\end{array}$} & \multirow[t]{2}{*}{$\chi^{2}$ (sig) } & \multirow[t]{2}{*}{ Phi } & \multirow{2}{*}{$\begin{array}{l}\text { Cramer's } \\
\text { V }\end{array}$} \\
\hline & & Yes & No & Maybe & Indifferent & & & & \\
\hline & Male & $100(80.6)$ & $24(19.4)$ & - & - & $124(62.0)$ & & & \\
\hline & Female & $62(81.6)$ & $14(18.4)$ & t & - & $76(38.0)$ & & & \\
\hline & Total & 162 & 38 & + & - & 200 & $0.027(0.870)$ & -0.012 & 0.012 \\
\hline \multirow[t]{5}{*}{ Gwagwalada } & Gender & \multicolumn{4}{|c|}{ Vaccination Response Freq. (\%) } & \multirow{2}{*}{\begin{tabular}{|l} 
Gender \\
Frequency
\end{tabular}} & & & \\
\hline & & Yes & No & Maybe & Indifferent & & & & \\
\hline & Male & $81(61.8)$ & $48(36.6)$ & $2(1.5)$ & $0(0.0)$ & $131(65.5)$ & & & \\
\hline & Female & $39(56.5)$ & $27(39.1)$ & $0(0.0)$ & $3(4.3)$ & $69(34.5)$ & & & \\
\hline & Total & 120 & 75 & 2 & 3 & 200 & $7.036(0.071)$ & 0.188 & 0.188 \\
\hline \multirow[t]{5}{*}{ Kuje } & Gender & \multicolumn{4}{|c|}{ Vaccination Response Freq. (\%) } & \multirow{2}{*}{$\begin{array}{l}\text { Gender } \\
\text { Frequency }\end{array}$} & & & \\
\hline & & Yes & No & Maybe & Indifferent & & & & \\
\hline & Male & $113(88.5)$ & $15(11.7)$ & 5 & - & $128(64.0)$ & & & \\
\hline & Female & $56(77.8)$ & $16(22.2)$ & - & - & $72(36.0)$ & & & \\
\hline & Total & 169 & 31 & F & F & 200 & $3.881(0.049)$ & 0.139 & 0.139 \\
\hline \multirow[t]{5}{*}{ Kwali } & Gender & \multicolumn{4}{|c|}{ Vaccination Response Freq. (\%) } & \multirow{2}{*}{\begin{tabular}{|l} 
Gender \\
Frequency
\end{tabular}} & & & \\
\hline & & Yes & No & Maybe & Indifferent & & & & \\
\hline & Male & $120(97.6)$ & $3(2.4)$ & - & - & $123(61.5)$ & & & \\
\hline & Female & $73(94.8)$ & $4(5.2)$ & - & - & $77(38.5)$ & & & \\
\hline & Total & 193 & 7 & 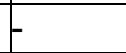 & - & 200 & $1.065(0.302)$ & 0.073 & 0.073 \\
\hline \multirow[t]{5}{*}{ Abaji } & Gender & \multicolumn{4}{|c|}{ Vaccination Response Freq. (\%) } & \multirow{2}{*}{\begin{tabular}{|l|} 
Gender \\
Frequency
\end{tabular}} & & & \\
\hline & & Yes & No & Maybe & Indifferent & & & & \\
\hline & Male & $103(81.7)$ & $23(1.8)$ & - & - & $126(63.0)$ & & & \\
\hline & Female & $57(77.0)$ & $17(23.0)$ & - & - & $74(37.0)$ & & & \\
\hline & Total & 160 & 40 & F & - & 200 & $3.162(0.531)$ & 0.126 & 0.126 \\
\hline \multirow[t]{5}{*}{ Bwari } & Gender & \multicolumn{4}{|c|}{ Vaccination Response Freq. (\%) } & \multirow{2}{*}{\begin{tabular}{|l|} 
Gender \\
Frequency
\end{tabular}} & & & \\
\hline & & Yes & No & Maybe & Indifferent & & & & \\
\hline & Male & $104(83.9)$ & $20(16.1)$ & - & - & 124 & & & \\
\hline & Female & $65(85.5)$ & $11(14.5)$ & - & - & 76 & & & \\
\hline & Total & 169 & 31 & 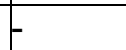 & - & 200 & $0.099(0.754)$ & -0.022 & 0.022 \\
\hline Total & & $973(81.0)$ & $222(18.5)$ & $2(0.16)$ & $3(0.25)$ & 1200 & & & \\
\hline
\end{tabular}


Table 2: Distribution of Vaccination response against COVID-19 vaccine in Abuja-FCT, Nigeria

\begin{tabular}{|c|c|c|c|c|c|c|}
\hline \multirow[t]{2}{*}{ Location } & \multirow[t]{2}{*}{ Response } & \multicolumn{2}{|c|}{ Gender } & \multirow[t]{2}{*}{$x^{2}$} & \multirow[t]{2}{*}{ Phi } & \multirow[t]{2}{*}{ Cramer's V } \\
\hline & & Male & Female & & & \\
\hline \multirow[t]{7}{*}{ AMC } & Believe in God & $6(4.8)$ & $2(2.6)$ & & & \\
\hline & Lack of trust for the vaccine & $4(3.2)$ & $1(1.3)$ & & & \\
\hline & Dislike drugs/injections & $12(9.7)$ & $9(11.8)$ & & & \\
\hline & Fear & $1(0.8)$ & $1(1.3)$ & & & \\
\hline & It won't protect/remedy & $1(0.8)$ & $0(0.0)$ & & & \\
\hline & No reason/undecided & $0(0.0)$ & $1(1.3)$ & & & \\
\hline & Total & 24 & 14 & $3.844(0.698)$ & 0.139 & 0.139 \\
\hline \multirow{2}{*}{\multicolumn{2}{|c|}{ GwagwaladaResponse }} & \multicolumn{2}{|c|}{ Gender } & \multirow[t]{2}{*}{$x^{2}$} & \multirow[t]{2}{*}{ Phi } & \multirow[t]{2}{*}{ Cramer's V } \\
\hline & & Male & Female & & & \\
\hline & Believe in God & $1(0.8)$ & $1(1.4)$ & & & \\
\hline & Lack of trust for the vaccine & $25(19.1)$ & $20(23.2)$ & & & \\
\hline & No virus infection in Nigeria & $6(4.7)$ & $3(4.3)$ & & & \\
\hline & Personal reasons & $5(3.8)$ & $0(0.0)$ & & & \\
\hline & Not interested & $2(1.6)$ & $0(0.0)$ & & & \\
\hline & $\begin{array}{l}\text { It won't protect/not a } \\
\text { Remedy }\end{array}$ & $1(0.8)$ & $1(1.2)$ & & & \\
\hline & Need for proper education & $3(2.4)$ & $0(0.0)$ & & & \\
\hline & No reason/undecided & $3(2.4)$ & $0(0.0)$ & & & \\
\hline & No to occult/new world order & $1(1.6)$ & $1(1.4)$ & & & \\
\hline & $\begin{array}{l}\text { Undeveloped \& clinical trial } \\
\text { of vaccine }\end{array}$ & $0(0.0)$ & $1(1.4)$ & & & \\
\hline & Deadly side effect & $1(0.8)$ & $0(0.0)$ & & & \\
\hline & Total & 48 & 27 & $17.926(0.592)$ & 0.299 & 0.299 \\
\hline \multirow[t]{9}{*}{ Kuje } & \multirow[t]{2}{*}{ Response } & \multicolumn{2}{|c|}{ Gender } & $\chi^{2}$ & \multirow[t]{2}{*}{ Phi } & \multirow[t]{2}{*}{ Cramer's V } \\
\hline & & Male & Female & & & \\
\hline & Believe in God & $9(7.0)$ & $7(9.7)$ & & & \\
\hline & Lack of trust for the vaccine & $0(0.0)$ & $2(2.8)$ & & & \\
\hline & Dislike drugs/injections & $4(3.1)$ & $6(8.3)$ & & & \\
\hline & Fear & $1(0.8)$ & $0(0.0)$ & & & \\
\hline & Not interested & $0(0.0)$ & $1(1.4)$ & & & \\
\hline & Prefer herbal remedy & $1(0.8)$ & $0(0.0)$ & & & \\
\hline & Total & 15 & 16 & $9.977(0.126)$ & 0.223 & 0.223 \\
\hline \multirow[t]{5}{*}{ Kwali } & Response & & ender & $x^{2}$ & Phi & Cramer's V \\
\hline & & Male & Female & & & \\
\hline & Believe in God & $1(0.8)$ & $2(2.6)$ & & & \\
\hline & Dislike drugs/injections & $2(1.6)$ & $2(2.6)$ & & & \\
\hline & Total & 3 & 4 & $1.266(0.531)$ & 0.08 & 0.08 \\
\hline Abaji & Response & & ender & $x^{2}$ & Phi & Cramer's V \\
\hline & & Male & Female & & & \\
\hline & Believe in God & $3(2.4)$ & $5(6.8)$ & & & \\
\hline & Lack of trust for the vaccine & $8(6.3)$ & $4(5.4)$ & & & \\
\hline & Dislike drugs/injections & $4(3.2)$ & $3(4.1)$ & & & \\
\hline & Fear & $3(2.4)$ & $2(2.7)$ & & & \\
\hline & No virus infection in Nigeria & $2(1.6)$ & $1(1.4)$ & & & \\
\hline & Personal reasons & $1(0.8)$ & $0(0.0)$ & & & \\
\hline & Not interested & $1(0.8)$ & $0(0.0)$ & & & \\
\hline & No reason/undecided & $0(0.0)$ & $1(1.4)$ & & & \\
\hline & Not produced in Nigeria & $1(0.8)$ & $1(1.4)$ & & & \\
\hline & Total & 23 & 17 & $7.637(0.745)$ & 0.195 & 0.195 \\
\hline Bwari & Response & & ender & $\chi^{2}$ & Phi & Cramer's V \\
\hline & & Male & Female & & & \\
\hline & Believe in God & $8(6.5)$ & $6(7.9)$ & & & \\
\hline & Dislike drugs/injections & $7(5.6)$ & $3(3.9)$ & & & \\
\hline & No virus infection in Nigeria & $5(4.0)$ & $2(2.6)$ & & & \\
\hline & Total & 20 & 11 & $0.691(0.875)$ & 0.59 & 0.59 \\
\hline Total & & $133(59.9)$ & $89(40.0)$ & & & \\
\hline
\end{tabular}


Table 3: Demographic distribution of COVID-19 Vaccination respondents in Abuja-FCT, Nigeria

\begin{tabular}{|c|c|c|c|c|c|c|c|c|c|c|c|c|c|c|c|c|c|c|c|c|c|c|c|c|c|}
\hline & \multirow{3}{*}{\begin{tabular}{|l} 
Location \\
\\
AMAC \\
\end{tabular}} & \multicolumn{4}{|c|}{ Religion } & \multicolumn{8}{|c|}{ Marital Status } & \multicolumn{8}{|c|}{ Educational Status } & \multicolumn{4}{|c|}{ Occupation } \\
\hline & & \multicolumn{2}{|c|}{ Christianity } & \multicolumn{2}{|c|}{ Islam } & \multicolumn{2}{|c|}{ Single } & \multicolumn{2}{|c|}{ Married } & \multicolumn{2}{|c|}{ Widow } & \multicolumn{2}{|c|}{ Widower } & \multicolumn{2}{|c|}{$\begin{array}{c}\text { No } \\
\text { Qualification }\end{array}$} & \multicolumn{2}{|c|}{ Undergraduate } & \multicolumn{2}{|c|}{ Graduate } & \multicolumn{2}{|c|}{ Postgraduate } & \multicolumn{2}{|c|}{$\begin{array}{c}\text { Public } \\
\text { (Formal) }\end{array}$} & \multicolumn{2}{|c|}{$\begin{array}{c}\text { Private } \\
\text { (Informal) }\end{array}$} \\
\hline & & Yes & No & Yes & No & Yes & No & Yes & No & \begin{tabular}{|l|l} 
Yes & \\
\end{tabular} & No & Yes & No & Yes & No & Yes & No & Yes & No & Yes & No & Yes & No & Yes & No \\
\hline \multirow{20}{*}{ Page | } & 3967 & 89 & 13 & 73 & 25 & 85 & 13 & 77 & 25 & 0 & 0 & 0 & 0 & 0 & 0 & 76 & 22 & 83 & 16 & 3 & 0 & 51 & 6 & 111 & 32 \\
\hline & $(\%)$ & 87.3 & 12.7 & 74.5 & 25.5 & 86.7 & 13.3 & 75.5 & 24.5 & \begin{tabular}{|l|l|}
0.0 & 0 \\
\end{tabular} & 0.0 & 0.0 & 0.0 & 0.0 & 0.0 & 38.0 & 11.0 & 41.5 & 8.0 & 1.5 & 0.0 & 25.5 & 3.0 & 55.5 & 16.0 \\
\hline & $\chi^{2}$ & \multicolumn{4}{|c|}{$5.292(0.021)$} & \multicolumn{8}{|c|}{$4.106(0.043)$} & \multicolumn{8}{|c|}{$4.990(0.417)$} & \multicolumn{4}{|c|}{$46.989(0.0001)$} \\
\hline & Gwags & 101 & 66 & 19 & 14 & 81 & 58 & 39 & 22 & 0 & 0 & 0 & 0 & 3 & 2 & 63 & 42 & 45 & 32 & 8 & 4 & 39 & 19 & 82 & 55 \\
\hline & $(\%)$ & 60.5 & 37.7 & 57.6 & 36.4 & 58.3 & 38.8 & 63.9 & $34.4 \mid$ & \begin{tabular}{|l|l|}
0.0 & 0 \\
\end{tabular} & 0.0 & 0.0 & 0.0 & 60.0 & 40.0 & 61.0 & 39.0 & 60.8 & 39.2 & 38.0 & 62.0 & 19.5 & 9.5 & 41.0 & 27.5 \\
\hline & $\chi^{2}$ & \multicolumn{4}{|c|}{$10.766(0.013)$} & \multicolumn{8}{|c|}{$1.337(0.720)$} & & & & $858(0$. & 167) & & & & & 31.65 & $7(1.0$ & \\
\hline & Kuje & 94 & 16 & 75 & 15 & 80 & 9 & 85 & 22 & 2 & 0 & 2 & 0 & 0 & 0 & 75 & 18 & 94 & 13 & 0 & 0 & 64 & 6 & 106 & 26 \\
\hline & $(\%)$ & 85.5 & 14.5 & 83.3 & 16.7 & 89.9 & 10.1 & 79.4 & 20.61 & \begin{tabular}{|l|l|}
100 & 0 \\
\end{tabular} & 0.0 & 0.0 & 0.0 & 0.0 & 0.0 & 37.5 & 9.0 & 47.0 & 6.5 & 0.0 & 0.0 & 32.0 & 3.0 & 53.0 & 13.0 \\
\hline & $\chi^{2}$ & & $.17(0$ & 680) & & & & & $798(0$ & $(0.187)$ & & & & & & & $68(0.2$ & 80) & & & & & 4.991 & $1(0.00$ & \\
\hline & Kwali & 109 & 5 & 84 & 2 & 57 & 3 & 133 & 4 & 2 & 0 & 1 & 0 & 0 & 0 & 131 & 5 & 62 & 0 & 0 & 0 & 38 & 1 & 155 & 6 \\
\hline & $(\%)$ & 95.6 & 4.4 & 97.7 & 2.3 & 95.0 & 5.0 & 97.1 & \begin{tabular}{l|l}
2.9 & 1
\end{tabular} & \begin{tabular}{|l|l}
100 & 0 \\
\end{tabular} & 0.0 & 100 & 0.0 & 0.0 & 0.00 & 65.5 & 2.5 & 31.0 & 0.0 & 0.0 & 0.0 & 19.0 & \begin{tabular}{|l|}
1.0 \\
\end{tabular} & 77.5 & 3.0 \\
\hline & $\chi^{2}$ & & $616(0$ & .432) & & & & & $645(0$ & $(0.886$ & & & & & & & $254(0$. & 001) & & & & & 7.34 & $4(0.43$ & \\
\hline & Abaji & 93 & 21 & 70 & 16 & 79 & 12 & 83 & 25 & 1 & 0 & 0 & 0 & 3 & 0 & 99 & 21 & 60 & 11 & 2 & 7 & 37 & 22 & 115 & 26 \\
\hline & $(\%)$ & 81.5 & 18.4 & 81.2 & 18.6 & 85.7 & 13.2 & 75.0 & 23.1 & \begin{tabular}{|l|l|}
0.5 & 0 \\
\end{tabular} & 0.0 & 0.0 & 0.0 & 100 & 0.0 & 49.5 & 10.5 & 30.0 & 5.5 & 1.0 & 3.5 & 18.5 & 11.0 & 57.5 & 13.0 \\
\hline & $\chi^{2}$ & & $836(0$ & $.586)$ & & & & & $495(0$ & $(0.592)$ & & & & & & & $584(0$ & 171) & & & & & 42.32 & $7(0.0$ & \\
\hline & Bwari & 91 & 15 & 78 & 16 & 94 & 9 & 72 & 22 & 1 & 0 & 2 & 0 & 3 & 0 & 92 & 13 & 74 & 18 & 0 & 0 & 60 & 13 & 110 & 20 \\
\hline & $(\%)$ & 85.8 & 14.2 & 74.5 & 17.0 & 91.3 & 8.7 & 76.6 & $23.4 \mid 1$ & \begin{tabular}{|l|l|}
100 & 0 \\
\end{tabular} & 0.0 & 100 & 0.0 & 1.5 & 0.0 & 46.0 & 6.5 & 37.0 & 9.0 & 0.0 & 0.0 & 30.0 & 5.0 & 55.0 & 10.0 \\
\hline & $\chi^{2}$ & & $313(0$ & .576) & & & & & $630(0$ & $(\mathbf{0 . 0 3 5})$ & & & & & & & $09(0$ & 40) & & & & & 5.513 & $(0.00$ & \\
\hline & Total & 577 & 136 & 399 & \begin{tabular}{|l|}
88 \\
\end{tabular} & 476 & \begin{tabular}{|l|}
104 \\
\end{tabular} & \begin{tabular}{|l|l|}
489 \\
\end{tabular} & 120 & \begin{tabular}{l|l}
6 & 0
\end{tabular} & & 5 & $\mathbf{0}$ & 9 & 2 & 536 & 121 & \begin{tabular}{|l|}
418 \\
\end{tabular} & 90 & 13 & 11 & 289 & \begin{tabular}{|l|}
67 \\
\end{tabular} & \begin{tabular}{|l|}
679 \\
\end{tabular} & 165 \\
\hline & & & 120 & & & & & & 120 & 00 & & & & & & & 1200 & & & & & & & 200 & \\
\hline
\end{tabular}

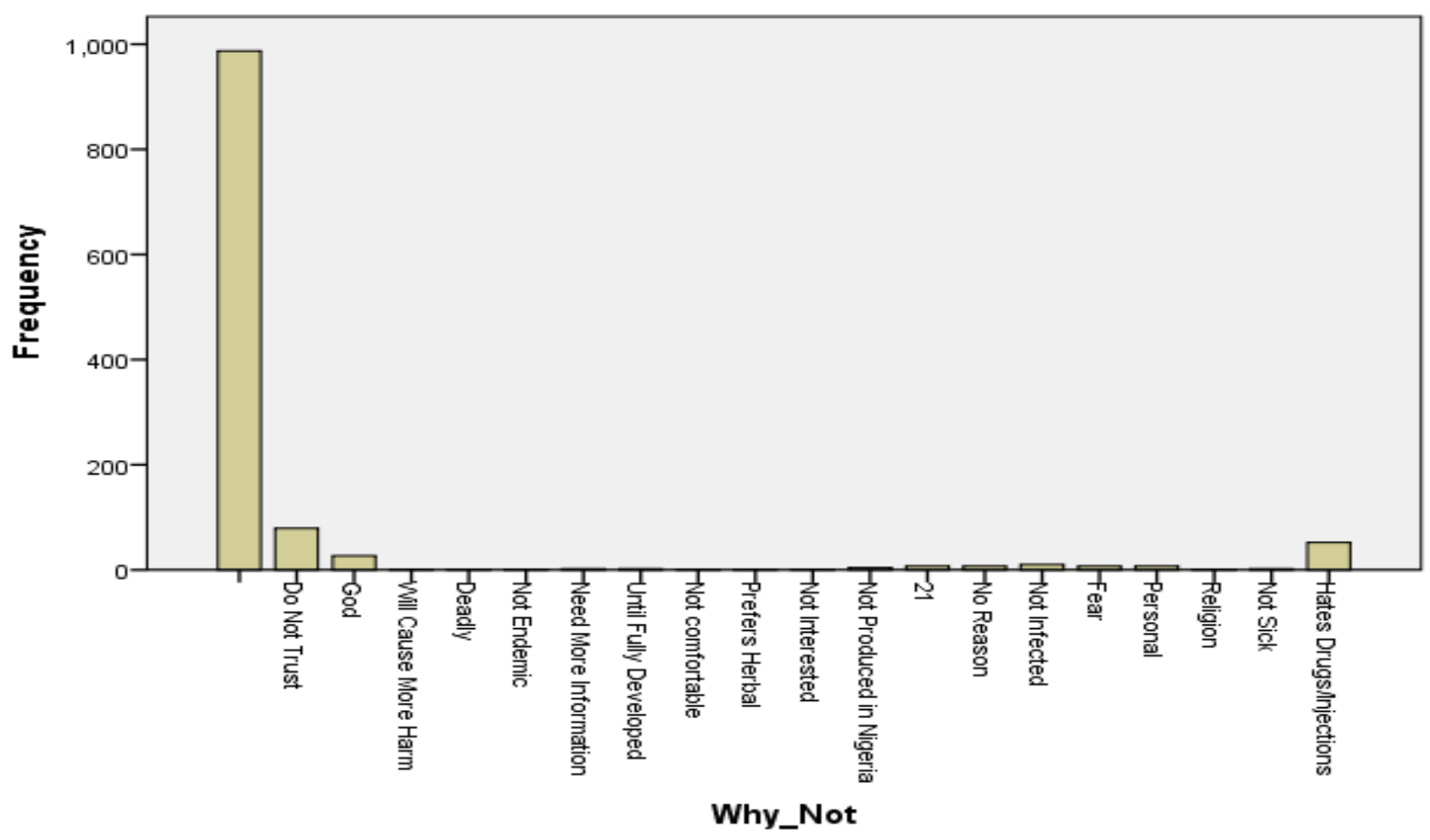

Figure 1: Reasons for apathy against anticipated COVID-19 vaccination in Abuja 
The current study shows that, $5(0.4 \%)$ of the participants were indifferent to receiving COVID19 vaccine, while $219(18.3 \%)$ of the participants did not support the use of COVID-19 vaccine for various reasons, as seen (Fig. 1). Of the $18.3 \%$

Page | 3968 who said "No," 79 (6.6\%) had no believe in the protective effect of vaccination against the virus and $27(2.3 \%)$ believe in God for protection against the virus, and that getting vaccinated will only go against their religious beliefs; while a handful believe the disease is not prevalent in Nigeria and that the vaccine may be deadly and cause more harm, making them uncomfortable and uninterested.

Others $(0.8 \%)$ say they are free of infection, and $(0.6 \%)$ respondents were uninterested in the vaccine due to their apprehension of injectable drugs (4.3\%). Respondents $(0.2 \%)$ want more knowledge before the vaccine is fully developed since much of the research and development was done outside of Nigeria $(0.3 \%)$. Some respondents $(0.6 \%)$ had no reason for rejecting to be vaccinated other than their individual dislike for it. However, $0.1 \%$ of participants would rather use natural remedies than the vaccine suggested.

\section{Distribution of Vaccination response against COVID-19 vaccine in Abuja-FCT, Nigeria}

Table 2 indicates the responses of respondents who said they would refuse the vaccines if they were made available. The main reason for vaccine rejection was a lack of confidence in the vaccines, accompanied by respondents' faith in God. Although some respondents cited a fear of injections as a justification for refusing the vaccine, others are skeptical that the novel coronavirus exists in Nigeria.

\section{Demographic distribution of COVID-19 Vaccination respondents in Abuja-FCT, Nigeria}

The demographics of COVID-19 vaccination responses among residents of the Federal Capital Territory is shown in Table 3. Religion and marital status had a substantial impact on respondents' decisions about COVID-19 vaccines in Abuja Municipal Area Council, according to the findings. Religion influenced respondents' decision to embrace vaccines in Gwagwalada $(\mathrm{p}<0.05)$, while marital status influenced respondents' decision in Bwari $(\mathrm{p}<0.05)$.

\section{Discussion}

Despite the imminent signs of global transmission and danger, the coronavirus COVID -19 emerged when the country was unprepared, with little to no national preparedness plan. Following confirmation of the index case, the Federal Government of Nigeria (FGN), through the Federal Ministry of Health $(\mathrm{FMoH})$, Nigeria Centre for Disease Control (NCDC), and other related stakeholders, swung into motion, imposing an international travel ban, nationwide movement limits, social distancing, hand washing with soap and hand rubs, and complete lockdown in Lagos, Ogun, and Abuja.

Observational analysis of infection and activity patterns in Abuja reveals ineffective compliance with restriction directives by the public, especially in the Area Councils, where local and community spread could be striking and overwhelming during this study. Hence, necessitating an intervention approach that champions the use of efficient vaccines against the virus (Eyal et al., 2020), since respondents of the current study show a high degree of support for vaccination efforts.

However, the length of immunity, the number of necessary doses, and the possibility of re-infection in previously infected but recovered individuals are all possible roadblocks to its successful use (Lurie et al., 2020). Respondents' mixed feelings concerning the topic may be attributed to the controversial connection between 5G satellite network installations and the ongoing COVID-19 pandemic (Jacquet, 2020). Many would rather wait for more information on the vaccine noting that the vaccine may be deadly. Their fears may 
be due to some notable unscientific write-ups and videos shared on various social media platforms implying that the coronavirus is a deliberate weapon designed for global economic collapse to achieve a political agenda.

Page | 3969

Another community of people believes in God rather than vaccines because it goes against their religion. Their belief may stem from a series of sermons preached in religious gatherings, regardless of religious affiliation as Christians (Toromade, 2020) or Muslims. Other respondents stated that they were not sick because the disease is not severe in their vicinity as reported in other parts of the world. The perceived low community spread and disease burden may be related to the widespread use of Bacillus Calmette-Guerin (BCG) vaccines in Nigeria for infant immunization (Oladokun et al., 2009); the same reason Berg et al. (2020) opines a flattened curve for cases of COVID-19 infection and deaths in country-wide outbreaks (Berg et al., 2020).

Searches in English, French, and Chinese, from science databases and clinical trial repositories suggest that Bacillus Calmetter-Guerin (BCG) vaccines are not licensed for the cure or prevention of the novel coronavirus (WHO, 2020b). The effect of the vaccine against the virus is yet to be established, and the clinical significance remains unknown (Arts et al., 2018).

As a result, some respondents tend to use natural and home remedies rather than the proposed vaccine being produced outside of Nigeria because they fear injectable drugs. In conclusion, this finding suggests that COVID-19 infection and pandemic are legendary, and the residents of the study area were willing to consider vaccination if a vaccine was created. Policymakers should therefore provide funds to maintain ongoing containment initiatives and build a strong enabling climate for researchers to improve national, regional, and global collaborative research for rapid vaccine production.

\section{Conclusions}

The study emphasizes the need for enhanced public awareness about the COVID-19 vaccination to raise general knowledge about the vaccine's potential and to eliminate conspiracy theories and other factors found in the study that could obstruct the vaccine's smooth administration once it becomes accessible in the world.

\section{Competing interests}

Authors have declared that no competing interests exist.

\section{References}

Andersen, P.I., Ianevski, A., Lysvand, H., Vitkauskiene, A., Oksenych, V., Bjoras, M., Telling, K., Lutsar, I., Dumpis, U., Irie, Y., Tenson, T., Kantele, A. and Kainov, D. E. (2020). Discovery and Development of Safe-in-Man Broad-Spectrum Antiviral Agents. International Journal of Infectious Diseases, 93: 268-276.

Arts, R. J. W., Moorlag, S. L. C., Novakovic, B., Li, Y., Wang, S. Y., Oosting, M., Kumar, V., Xavier, R. J., Wijmenga, C., Joosten, L. A. B., Reusken, C., Benn, C. S., Aaby, P., Koopmans, M. P., Stunnenberg, H. G., van Crevel, R. and Netea, M. G. (2018). BCG vaccination Protects against Experimental Viral Infection in Humans through the induction of Cytokines Associated Trained Immunity. Cell Host Microbe, 23 (1): 89100 .

Berg, M. K., Yu, Q., Salvador, C. E., Melani, I. and Kitayama, S. (2020). Mandated Bacillus Calmette-Guerin (BCG) vaccination predicts flattened curves the spread of COVID-19. Science Advances, 5; 6 (32): eabc1463.

Caly, L., Druce, J. D., Catton, M. G., Jans, D. A. and Wagstaff, K. M. (2020). "The FDA- 
approved drug Ivermectin inhibits the replication of SARS-CoV2 in-Vitro. Antiviral Research, 178 (2020): 104805.

Corman, V. M., Muth, D., Niemeyer, D. and Page | 3970 Drosten, C. (2018). Hosts and Sources of Endemic Human Coronaviruses. Advances in Virus Research, 100: 163-188.

Cui, J., Fang, L. and Zheng-Li, S. (2019) Origin and evolution of pathogenic Coronaviruses. Nature Reviews Microbiology, 17:181-192.

Eyal, N., Lipsitch, M. and Smith, P. G. (2020). Human Challenge Studies to Accelerate Coronavirus Vaccine Licensure. Journal of Infectious Diseases DOI: 10.1093/infdis/jiaa152 published online March 31, 2020.

Federal Capital Territory (FCT, Nigeria; 2015). City Population - statistics, maps and charts. citypopulation.de October 26, 2015.

Gouglas, D., Thanh, L. T., Henderson, K., Kaloudis, A., Danielsen, T., Hammersland, N. C., Robinson, J. M., Heaton, P. M. and Rottingen, J. A. (2018). Estimating the cost of vaccine development against epidemic infectious diseases: a cost minimization study. Lancet Global Health, 6 (12): e1386e1396.

Graham, R. L., Donaldson, E. F. and Baric, R. S. (2013). A decade after SARS: strategies for controlling emerging coronaviruses. Nature Reviews Microbiology; 11, 836-848.

Guan, Y., Zheng, B. J., He, Y. Q., Liu, X. L., Zhuang, Z. X., Cheung, C. L., Luo, S. W., Li, P. H., Zhang, L. J., Guan, Y. J., Butt, K. M., Wong, K. L., Chan, K. W., Lim, W., Shortridge, K. F., Yuen, K. Y., Peiris, J. S. and Poon, L. L. (2003) Isolation and characterization of viruses related to the SARS coronavirus from animals in southern China. Science, 302, 276-278.
Haito, Y., Zihe, R. A., Jiang, H., Shi, Z., Qin, C., Xiao, G. and $\mathrm{Xu}, \mathrm{W}$. (2020). Structure of Mpro from COVID-19 virus and discovery of its inhibitors. Nature Doi: 10.1038/s41586-20-2223-y April 9, 2020.

Hilgenfeld, R. and Peiris, M. (2013). From SARS to MERS: 10 years of Research on Highly Pathogenic Human Coronaviruses. Antiviral Research, 100: 286-295.

Jacquet, R. (2020). Is there a link between 5G internet frequencies and the coronavirus? www.researchgate.net/profile/Russell_Jacq uet March 22, 2020.

Liu, Y., Eggo, R. M. and Kucharski, A. J. (2020) Secondary attack rate and super spreading events for SARS-CoV-2. Lancet, (20) 30462-1.

Li, W., Shi, Z., Yu, M., Ren, W., Smith, C., Epstein, J. H., Wang, H., Crameri, G., Hu, Z., Zhang, H., Zhang, J., McEachern, J., Field, H., Daszak, P., Eaton, B. T., Zhang, S. and Wang, L. F. (2005). Bats are natural reservoirs of SARS-like coronaviruses. Science, 310, 676-679.

Lurie, N., Saville, M., Hatchett, R. and Halton J. (2020). Developing CoVID-19 Vaccines at pandemic speed. New England Journal of Medicine Doi: 10.1056/NEJMp 2005630.

Mohit, T., Tripti, T., Manal, K., Anit, N. R., Deepa, C. and Onyema, E. M. (2020). Detection of Coronavirus Disease in Human Body Using Convolutional Neural Network. International Journal of Advanced Science and Technology; 29 (8), 2861-2866.

NCDC (2020a). COVID-19 case update in Nigeria www.ncdc.gov.ngApril 17, 2020.

NCDC (2020b). Guideline for COVID-19 control in Nigeria www.ncdc.gov.ng 
Ohadike, D. C. (1991). Diffusion and Physiological responses to the influenza pandemic of 1918-19 in Nigeria. Social Science and Medicine, 32 (12): 1393-1399.

Page | 3971 Olabode, H. O. K., Mailafia, S., Adah, B. M. J., Nyambee, P. and Bello, R. H. (2011). Antibiogram of bacterial isolates associated reproductive abnormalities in sheep in Gwagwalada-FCT, Nigeria. Journal of Agriculture and Veterinary Science, 3: 2027.

Oladokun, R. E., Lawoyin, T. O. and Adedokun, B. O. (2009). Immunization Status and Its Determinants Among Children of Female Traders in Ibadan, South-Western Nigeria. African Journal of Medicine and Medical Sciences, 38 (1): 9-15.

Onyema, E.M., Eucheria, N. C., Obafemi, F. A., Sen, S., Atonye, F. G., Sharma, A. and Alhuseen, O. A. (2020a). Impact of Coronavirus Pandemic on Education. Journal of Education and Practice, 11(13), 108- 121. https://doi.org/10.7176/JEP/11$13-12$.

Onyema, E. M., Nwafor, C., Obafemi, F. A., Sen, S., Atonye, F. G., Sharma, A. and Alsayed, A. O. (2020b). Pedagogical use of Mobile technologies during Coronavirus School Closure. The Journal of Computer Science and its Applications, 27 (2), 97-110.

Su, S., Wong, G., Shi, W., Liu, J., Lai ACK, Zhou J, Liu W, Bi Y, Gao GF (2016). Epidemiology, genetic recombination, and pathogenesis of coronaviruses. Trends in Microbiology; 24: 490-502. Doi: 101016/j.tim.2016.03.003pmid:2701251.

Toromade, S. (2020). UK agency sanctions Pastor Oyakhilome's channel over coronavirus, $5 \mathrm{G}$ conspiracy claims. https://www.pulse .ng/news/local/oyakhilome-ofcom- sanctions-loveworld-over-coronavirus-5gclaims/gp2z9s1 Accessed May18, 2020

WHO (2020a). Coronavirus Disease (COVID-19) Pandemic

http://www.who.int/emergencies/diseases/ novel-coronavirus-2019 Accessed April 8, 2020 .

WHO (2020b). Bacille Calmette-Guerin (BCG) and vaccination and COVID-19 www.Who.Int April 12, 2020.

WHO (2020c) DRAFT landscape of COVID- 19 candidate vaccines. https://www.who.int/blueprint/prioritydiseases/key-action/novel-coronaviruslandscapencov.pdf?ua $=1$. Accessed March 20, 2020.

WHO (2020d). Coronavirus Disease (COVID19): WHO to commence vaccine trials in Nigeria. http://www.who.int Accessed May 2, 2020.

Woo, P. C., Lau, S. K., Lam, C. S., Lau, C. C., Tsang, A.K., Lau, J. H., Bai, R., Teng, J. L., Tsang, C. C., Wang, M., Zheng, B. J., Chan, K. H. and Yuen, K. Y. (2012). Discovery of seven novel mammalian and avian coronaviruses in the genus delta corona virus supports bat coronaviruses as the gene source of alpha coronavirus and beta corona virus and avian coronaviruses as the gene source of gamma corona virus and delta coronavirus. Journal of Virology; 86, 39954008 .

Wu, J. T., Leung, K., Bushman, M., Kishore, N., Niehus, R., de Salazar, P. M., Cowling, B. J., Lipsitch, M. and Leung, G. M. (2020) Estimating clinical severity of COVID-19 from the transmission dynamics in Wuhan, China. Nature. https://doi.org/10.1038/s41 591-020-0822-7. 
Xing, Z. L., Xue, B. and Zhi, Z. (2020). The epidemiological characteristics of an outbreak of 2019 novel coronavirus diseases (COVID-19) in China. Epidemiology Working Group for NCIP Epidemic Response, Chinese Center for Disease Control and Prevention, 10; 41(2):145-151.

Yang, C. W., Peng, T. T., Hsu, H. Y., Lee, Y. Z., Wu, S. H., Lin, W. H., Ke, Y. Y., Hsu, T. A., Yeh, T. K., Huang, W. Z., Lin, J. H., Sytwu, H. K., Chen, C. T. and Lee, S. J. (2020). Repurposing old drugs as antiviral agents for coronaviruses. Biomedical Journal, 43, 368-374.

Zhang, L., Lin, D., Kusov, Y., Nian, Y., Ma, Q., Wang, J., Von, B. A. Leyssen, P., Lanko, K., Neyts, J., de Wilde, A., Snijder, E. J., Liu, H. and Hilgenfeld, R. (2020). $\alpha$-Ketoamides as Broad-Spectrum Inhibitors of Coronavirus and Enterovirus Replication: Structure-Based Design,
Synthesis, and Activity Assessment. Journal of Medical Chemistry https://dx.doi.org/10.1021/acs.jmedchem.9 b01828.

Zhou, P., Xing-Lou. Y., Xian-Guang, W., Ben, H., Lei, Z., Wei, Z., Hao-Rui, S. et al (2020). A pneumonia outbreak associated with a new coronavirus of probable bat origin. Nature, 579: 270-273.

Zou, L., Ruan, F., Huang, M., Liang, L., Huang, H., Hong, Z., Yu, J., Kang, M., Song, Y., Xia, J., Guo, Q., Song, T., He, J., Yen, H., Peiris, M. and Wu, J. (2020).SARS-CoV-2 Viral Load in Upper Respiratory Specimens of Infected Patients. National England Journal of Medicine, 19; 382 (12): 11771179. 